\title{
Assessment of Physicochemical Characteristics and some Heavy Metals of Ossiomo River, Ologbo - A Tributary of Benin River, Southern Nigeria
}

\section{*1 IKHUORIAH, SO; ORONSAYE, CG.}

\author{
Department of Animal and Environmental Biology, \\ Faculty of Life Sciences, University of Benin, P.M.B 1154, Edo state, Nigeria \\ Corresponding Author E-mail: Suleman.ikhuoriah@uniben.edu \\ Tel: +2348037368623
}

\begin{abstract}
Assessment of the physicochemical characteristics and some heavy metals of Ossiomo River, Ologbo- a tributary of Benin River, Southern Nigeria was carried out from April 2012 to December 2012. Three stations were studied from upstream to downstream with a distance of about 2 kilometres between each station. A total of twenty-two (22) physicochemical parameters and some heavy metals were studied. Air temperature ranged from the mean 27.01 to $29.57^{\circ} \mathrm{C}$, water temperature 25.87 to $27.56^{\circ} \mathrm{C}$, depth 1.32 to $1.705 \mathrm{~m}$, flow velocity 0.08 to $0.13 \mathrm{~m} / \mathrm{s}$, transparency 1.01 to $1.30 \mathrm{~m}, \mathrm{pH} 5.76$ to 6.01 , electrical conductivity 62.03 to $70.11 \mu \mathrm{S} / \mathrm{cm}$, turbidity 3.97 to $4.39 \mathrm{NTU}$, total suspended solid 5.01 to $5.80 \mathrm{mg} / \mathrm{l}$, total solid 38.82 to $42.11 \mathrm{mg} / \mathrm{l}$, total dissolve solid 29.60 to $33.84 \mathrm{mg} / \mathrm{l}$, DO 7.12 to $7.54 \mathrm{mg} / \mathrm{l}, \mathrm{BOD}_{5} 1.51$ to $2.60 \mathrm{mg} / \mathrm{l}$, alkalinity 48.63 to $53.28 \mathrm{mg} / 1$, the cations (sodium 1.35 to $1.43 \mathrm{mg} / 1$, potassium 0.25 to $0.26 \mathrm{mg} / \mathrm{l}$, calcium 0.92 to $1.00 \mathrm{mg} / \mathrm{l}$, magnesium 0.44 to $0.52 \mathrm{mg} / \mathrm{l}$ ), chloride 26.44 to $36.39 \mathrm{mg} / \mathrm{l}$, and the nutrient components (phosphorus 0.25 to $0.33 \mathrm{mg} / \mathrm{l}$, nitrate 0.16 to $0.20 \mathrm{mg} / \mathrm{l}$, sulphate 0.88 to $0.94 \mathrm{mg} / \mathrm{l}$ ). Heavy metals level were generally low ranging from 0.05 to $2.61 \mathrm{mg} / \mathrm{l}$ (cadmium 0.05 to $0.51 \mathrm{mg} / \mathrm{l}$, lead 0.06 to $0.09 \mathrm{mg} / \mathrm{l}$, zinc 0.11 to $0.12 \mathrm{mg} / \mathrm{l}$, copper 0.39 to $0.41 \mathrm{mg} / \mathrm{l}$, iron 2.00 to $2.61 \mathrm{mg} / \mathrm{l}$. Mean across stations were compared using Analysis of Variance and only three characteristics namely, air temperature, water temperature and flow velocity were significant. In station 1 (upstream), air temperature and water temperature were significantly higher than other 2 stations (downstream) while the flow velocity was significantly faster in station 3 than both upstream and midstream stations. A marked seasonal significant faster flow velocity was recorded in the wet than in the dry season. Furthermore, a significant $(\mathrm{P}<0.05)$ pattern of seasonal variation was observed in seven (7) characteristics, total solids, calcium, magnesium, chloride, phosphate, nitrate and sulphate. Anthropogenic activities had negatively impacted on station 2 of the river, although the recorded values were still within acceptable limits. (C) JASEM
\end{abstract}

KEY WORDS: Physicochemical, Characteristics, Ossiomo River, Assessment, Heavy metals, Ologbo http://dx.doi.org/10.4314/jasem.v20i2.30

\section{Introduction}

It is well known that clean water is absolutely essential for several purposes for healthy living (Mandalam et al., 2009).The functioning of an aquatic ecosystem and its stability to support life forms depend, to a great extent, on the physicochemical characteristics of its water. The key feature of an ecosystem is the interaction among the biotic and abiotic components.

Water is one of the most important components of life and life without it is impossible. However due to increasing anthropogenic activities and some natural processes, the quality of water is decreasing continuously and is posing a great threat to all forms of life including humans. Polluted water is the major cause for the spread of many epidemics and some serious diseases like cholera, tuberculosis, typhoid, diarrhea etc. Although several attempts have been made by a number of researchers (Caraco et al., 2003; Donohue et al., 2006) to study various aspects of water

\section{Corresponding Author E-mail:}

quality and the factors responsible for its degradation in order to formulate a significant control strategy all over the globe yet the problem is on the rise. The need of the hour is to take immediate steps to treat the water and minimize its negative impacts. The fast changing lifestyle of Ologbo community (Niger delta) for the last few decades including; the increasing rate of construction (brigde), development of small scale industrial units (including Presco Nig. Ltd) , increasing rate of transportation, human population, immense use of fertilizers and pesticides and use of some other harmful substance have brought a drastic change in the quality of water in almost all water bodies of valley including Ossiomo River which has posed a great threat to life.

Unfortunately, man in his ambivalent relationship with water has treated it with more contempt than respect. The socio-economic implications of water mismanagement are costly and avoidable 
(Orimoogunje, 2010); as unsustainable use could lead to degradation of water quality (Ajayi and Osibanjo 1981; Kings 1998). Besides the high demand for water, the rapid depreciation of water worldwide is exacerbated by the increasing human population, urbanization and industrial activities (Ajaiye and Adeleye 1977; Dike et al. 2004; Igbinosa and Okoh 2009). Heavy metal contamination in river is one of the major quality issues in developing countries (Silambarasan et al., 2012). Rivers are a dominant pathway for metals transport (Mohiuddin et al., 2010). Water pollution heightens the threshold of heavy metals and this usually poses serious threat to human health, natural and semi-natural ecosystems (Gopal and Sharma 1990; Fan, 1996; Battagglia et al. 2005). Non-essential heavy metal such as lead $(\mathrm{Pb})$ and cadmium $(\mathrm{Cd})$ are emitted and globally distributed mainly through industry, road traffic and fossil fuels consumption; and their effects on animals' health have been clearly established. For example, lead poisoning and high lead exposure in humans and animals have been a concern for more than a century (Wayland et al., 1999). Cadmium has been described as one of the most dangerous trace elements in food and the environment, not only for its high toxicity but for its high persistence in the environment (Battagglia et al., 2005). Although, other heavy metals, including zinc $(\mathrm{Zn})$, iron $(\mathrm{Fe})$ are essentially required for supporting biological processes, their environmental concentration beyond the acceptable limit constitutes serious toxicological problems (Perez-Lopez et al., 2006). It has been ascertained that human-related inputs are generally more significant than natural sources in their biogeochemical cycles. The aim of this paper is to present the data obtained as a consequence of the assessment of physicochemical characteristics and some heavy metals of a section of the Ossiomo River, Ologbo which is a tributary of Benin River, Southern Nigeria.

\section{MATERIALS AND METHODS}

Study Area: The study was carried out on a stretch of Ossiomo River (Latitudes 6030' - 6032'0"N; Longitude $5^{0} 39^{\prime}-5^{0} 40^{\prime} 30^{\prime \prime} \mathrm{E}$ ) (Figure 1), which is a tributary of Benin River, Southern Nigeria. Ossiomo River stretches over a $250 \mathrm{~km}$ distance within Edo state and Delta state, southern Nigeria. It is supplied by rivers Ikpoba, Okhuaihe and Akhaianwan. Ossiomo River drains into the Benin River at Koko, Delta state. The Benin River empties itself into the Atlantic Ocean (Tawari-Fufeyin et al., 2008).

The geology of the study area like the rest of the Niger Delta basin has been reviewed by Allen (1965), Short and Strauble (1967) and Asseez (1967). The lithostratigraphic unit is the Benin formation and a Miocene Age has been suggested for the lower part of the formation. The sedimentary deposit is Tertiary Scarp of Benin. The Benin formation extends to a depth of about $762.5 \mathrm{~m}$ and is located on top of the Agbado formation, which is composed of sandstone and coarse sand.

This study area falls within the well-known rainforest belt of Nigeria, with a wet season (March to October) and a dry season period (November to March) the following year. The Ologbo community, an adjacent settlement to Ossiomo River is essentially rural and it is situated in Ethiope West, Delta, Nigeria, its geographical coordinate are $6^{\circ} 3^{\prime} 0^{\prime \prime}$ North and $5^{\circ} 40^{\prime} 0^{\prime \prime}$ East (Tawari-Fufeyin et al., 2008). The Ossiomo River thus provides a source of water for domestic use especially for many rural settlers and communities. The river is fairly wide and flanked by secondary vegetation of rubber trees, Hevea brasilensis, palm trees, Elaeis guinensis, Bamboo trees Bambusa sp. and Shrubs. On the river are floating vegetation such as Salvinia sp., Lemna sp. and Eichorrnia crassipes (Tawari-Fufeyin et al., 2008). No major industry, except few logging merchants and few extractive industries is sited in this area. Farming is the major occupation of the inhabitants, while fishing is secondary (Tawari-Fufeyin et al., 2008).

Three sampling stations were chosen: Station 1 (Upstream), Station 2 (Midstream) and Station 3 (Downstream). The upstream station (Station 1) is about $2 \mathrm{~km}$ away from station 2 at Ologbo community. Apart from boating and fishing activities, the marginal vegetation here is mainly grasses and macrophytes like water hyacinth (E. crassipes). Station 2 is the wharf side at Ologbo community; the river has marginal vegetation encroaching into the river waterways consisting of shrubs and grasses. This station has highest level of human activities/disturbance, these include; bathing, swimming, and washing of clothes and household utensils. Station 3 (downstream) is also about $2 \mathrm{~km}$ downstream from station 2 . The human activities here include fishing, dredging, occasional oil spillage and lumbering.

Sampling: Samples were collected at monthly interval for 9 months from April 2012 to December 2012. Samplings were done between 0800hrs and 1200hrs on each day. Three sampling stations which were at least 2 kilometres from each other were established based on their characteristic features. Water samples meant for physicochemical laboratory tests were collected at each station. A total of 27 samples were collected and analysed during the study period. 


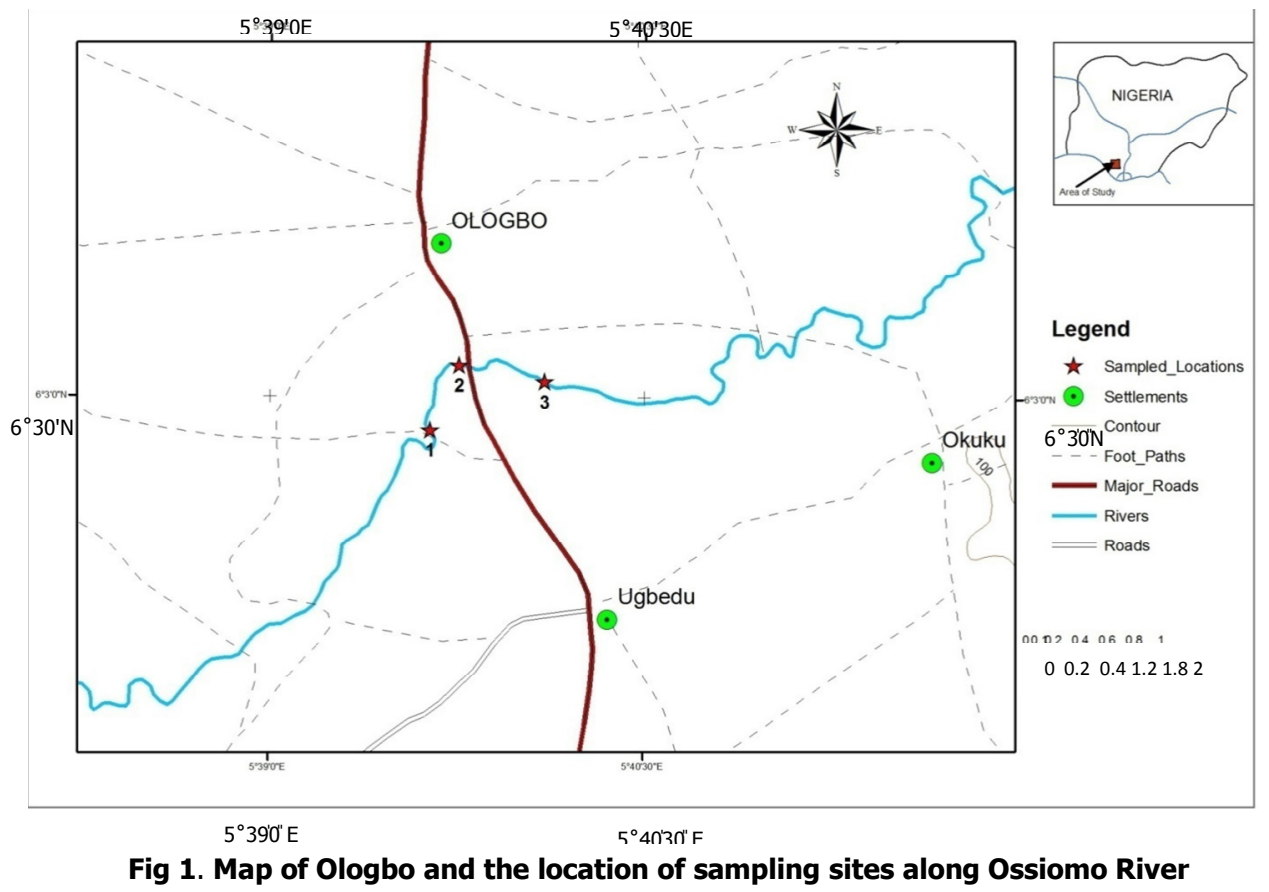

During these sampling procedures, in-situ measurement were also made for some of the physicochemical characteristics such as ambient air and surface water temperature, current conductivity, $\mathrm{pH}$, using Probe while depth and transparency was measured by $20 \mathrm{~cm}$ diameter Secchi disc. $\mathrm{pH}$ and conductivity were similarly measured using $\mathrm{HACH}$ digital meter. Dissolved Oxygen and Biochemical Oxygen Demand were estimated using Winkler's method (Boyd, 1979). The BOD was carried out after 5 days incubation at 200C. However other physicochemical tests conductivity and solids (Total, suspended and dissolved solids) total alkalinity, sodium, potassium, calcium, magnesium, chloride, phosphorus, nitrate and sulphate were determined in the laboratory titrimetically following the methods in APHA (1998). Other heavy metals: lead, cadmium, zinc, copper and chromium were determined by preparing standard solutions of known metal concentrations in water. Appropriate lamp of the metal was mounted and the spectrophotometer set at the normal wavelengths and readings recorded (APHA, 1998).

Data analysis: The results of the physicochemical characteristics were analyzed statistically and inter station comparisons were carried out to test for significant differences using the computer software Microsoft Excel (2010) package, SPSS 16.0 for performing analysis of variance (ANOVA) (Zar, 1984; Ogbeibu, 2005). Significance between wet and dry season in the three stations combined were analyzed using Mann-Whitney Unpaired t- Test.

\section{RESULTS AND DISCUSSION}

The results of the physicochemical characteristics and some heavy metals of water from Ossiomo River at the different sampling stations are summarized in Tables 1 and 2 . The mean air temperature ranged between $29.57^{\circ} \mathrm{C}$ (station 1) and $27.01^{\circ} \mathrm{C}$ (at station 2) while the mean water temperature ranged between $27.56^{\circ} \mathrm{C}$ (station 1) and $25.87^{\circ} \mathrm{C}$ (station 2). This is an indication that both air and water temperatures in the area are homogeneous. The air temperature was relatively high $\left(25-32^{\circ} \mathrm{C}\right)$ across the various months, while water temperature was relatively lower and cooler $\left(24.8-29.5^{\circ} \mathrm{C}\right)$ than the air temperature in each station of every sampled month. A high significant difference $(\mathrm{P}<0.01)$ was observed between the air and water temperature values at the study stations when subjected to One-way Analysis of Variance (ANOVA) such that only the station 1 which is the upstream (control station) has a distinct higher air temperature value compared to other two stations ( the mid and downstream which are not statistically different). The water temperature closely followed the trend of air temperature throughout the period of study. The dry season water temperature was higher than those recorded during the wet season, and this is typical of most tropical water, (Awachie, 1981). Also, a further comparison between wet and dry season of 
both water and air temperature shows no significant

difference, $\mathrm{P}>0.05$.

Table 1: Physicochemical characteristics (range, mean, $\pm \mathrm{SD}$ ) of the study stations in Ossiomo River April 2012 -Dec. 2012

\begin{tabular}{|c|c|c|c|c|c|c|c|c|c|c|c|}
\hline \multirow[t]{2}{*}{ Parameter } & \multicolumn{3}{|c|}{ Station 1} & \multicolumn{3}{|c|}{ Station 2} & \multicolumn{3}{|c|}{ Station 3} & \multirow{2}{*}{$\begin{array}{l}\text { FMEnv. } \\
\text { Permissible } \\
\text { Limits }\end{array}$} & \multirow{2}{*}{$\begin{array}{l}\text { WHO, } 2004 \\
\text { Standard } \\
\text { Value }\end{array}$} \\
\hline & Mean \pm SD & Min & $\operatorname{Max}$ & Mean \pm SD & Min & Max & Mean \pm SD & Min & Max & & \\
\hline Air Temperature $\left({ }^{\circ} \mathrm{C}\right)$ & $29.57^{\mathrm{a}} \pm 1.63$ & 26.60 & 32.30 & $27.01^{\mathbf{b}} \pm 1.48$ & 25.0 & 29.50 & $28.32^{\mathbf{b}} \pm 1.44$ & 26.50 & 30.40 & $\mathrm{~N} / \mathrm{A}$ & \\
\hline $\operatorname{Depth}(\mathrm{m})$ & $1.75 \pm 0.85$ & 0.63 & 2.70 & $1.47 \pm 0.19$ & 1.10 & 1.70 & $1.32 \pm 0.25$ & 1 & 1.75 & & \\
\hline Flow velocity $(\mathrm{m} / \mathrm{s})$ & $0.09^{b} \pm 0.05$ & 0.04 & 0.18 & $0.08^{b} \pm 0.04$ & 0.01 & 0.15 & $0.13^{\mathrm{a}} \pm 0.30$ & 0.1 & 0.19 & & \\
\hline Transparency (m) & $1.26 \pm 0.60$ & 0.50 & 2.30 & $1.30 \pm 0.22$ & 1.00 & 1.70 & $1.01 \pm 0.14$ & 0.70 & 1.20 & & \\
\hline $\mathrm{EC}(\mathrm{uS} / \mathrm{cm})$ & $70.11 \pm 22.85$ & 40 & 99 & $62.03 \pm 21.64$ & 28 & 90 & $64.1 \pm 24.15$ & 30 & 94 & N/A & 1000 \\
\hline Turbidity (NTU) & $4.37 \pm 0.82$ & 3.5 & 5.7 & $3.97 \pm 0.74$ & 3.1 & 5.2 & $4.19 \pm 0.82$ & 3.3 & 5.4 & $5.0 \mathrm{NTU}$ & \\
\hline TSS (mg/l) & $5.8 \pm 1.14$ & 4.5 & 7.5 & $5.52 \pm 0.91$ & 4.1 & 7 & $5.01 \pm 1.62$ & 2.3 & 7 & $<10$ & \\
\hline $\mathrm{TS}(\mathrm{mg} / \mathrm{l})$ & $42.11 \pm 10.00$ & 24.1 & 56.6 & $38.82 \pm 15.30$ & 22.7 & 76.3 & $40.73 \pm 19.39$ & 22.5 & 87.3 & & \\
\hline TDS (mg/l) & $33.84 \pm 11.39$ & 17.6 & 49.1 & $29.6 \pm 9.07$ & 18.6 & 45.7 & $30.57 \pm 9.75$ & 18.1 & 47.2 & 500 & 1000 \\
\hline $\mathrm{DO}(\mathrm{mg} / \mathrm{l})$ & $7.48 \pm 2.06$ & 5.6 & 12.1 & $7.12 \pm 1.20$ & 5.8 & 8.9 & $7.54 \pm 1.66$ & 5.4 & 10 & 5.0 & \\
\hline $\mathrm{BOD}_{5}(\mathrm{mg} / \mathrm{l})$ & $1.51 \pm 0.76$ & 0.14 & 1.80 & $2.6 \pm 1.35$ & 1.5 & 4.2 & $2.43 \pm 1.83$ & 1.82 & 3.81 & & \\
\hline Alkalinity (mg/l) & $53.28 \pm 11.66$ & 30.5 & 62 & $48.63 \pm 19.54$ & 24.4 & 91.5 & $50.53 \pm 21.64$ & 24.4 & 91.5 & & \\
\hline $\mathrm{K}(\mathrm{mg} / \mathrm{l})$ & $0.26 \pm 0.37$ & 0.03 & 1.23 & $0.25 \pm 0.36$ & 0.05 & 1.2 & $0.25 \pm 0.35$ & 0.03 & 1.17 & & \\
\hline $\mathrm{Ca}(\mathrm{mg} / \mathrm{l})$ & $1.00 \pm 0.50$ & 0.01 & 1.55 & $0.92 \pm 0.46$ & 0.04 & 1.43 & $0.97 \pm 0.51$ & 0.06 & 1.89 & & 200 \\
\hline $\mathrm{Mg}(\mathrm{mg} / \mathrm{l})$ & $0.52 \pm 0.32$ & 0.05 & 0.94 & $0.44 \pm 0.27$ & 0.05 & 0.8 & $0.48 \pm 0.28$ & 0.06 & 0.85 & & 200 \\
\hline $\mathrm{Cl}(\mathrm{mg} / \mathrm{l})$ & $36.39 \pm 24.55$ & 9.3 & 88.8 & $31.12 \pm 20.78$ & 7.75 & 74.4 & $26.44 \pm 24.46$ & 5.2 & 88.8 & 200 & 250 \\
\hline $\mathrm{P}(\mathrm{mg} / \mathrm{l})$ & $0.33 \pm 0.21$ & 0.1 & 0.76 & $0.25 \pm 0.11$ & 0.12 & 0.39 & $0.31 \pm 0.28$ & 0.07 & 0.94 & & \\
\hline $\mathrm{NO}_{3}{ }^{-}(\mathrm{mg} / \mathrm{l})$ & $0.19 \pm 0.22$ & 0.04 & 0.69 & $0.16 \pm 0.23$ & 0.02 & 0.71 & $0.20 \pm 0.22$ & 0.02 & 0.63 & 10.0 & 10 \\
\hline $\mathrm{SO}_{4}{ }^{-}(\mathrm{mg} / \mathrm{l})$ & $0.94 \pm 0.77$ & 0.12 & 2.56 & $0.88 \pm 0.66$ & 0.2 & 2.48 & $0.91 \pm 0.85$ & 0.22 & 2.97 & 500.0 & 250 \\
\hline
\end{tabular}

Table 2: Heavy Metal concentrations (range, mean, \pm SD) of the study stations in Ossiomo River April 2012- Dec 2012

\begin{tabular}{|c|c|c|c|c|c|c|c|c|c|c|}
\hline \multirow[t]{2}{*}{ Parameter } & \multirow[b]{2}{*}{ Mean \pm SD } & \multicolumn{2}{|c|}{ Station 1} & \multicolumn{2}{|c|}{ Station 2} & \multirow[b]{2}{*}{ Max } & \multicolumn{3}{|c|}{ Station 3} & \multirow{2}{*}{$\begin{array}{l}\text { FMEnv. } \\
\text { Permissible } \\
\text { Limits }\end{array}$} \\
\hline & & Min & Max & Mean \pm SD & Min & & Mean \pm SD & Min & Max & \\
\hline Cadmium (mg/l) & $0.05 \pm 0 . \mathrm{I} 6$ & 0.00 & 0.80 & $0.51 \pm 0.52$ & 0.00 & 2.01 & $0.08 \pm 0.08$ & 0.00 & 0.30 & \\
\hline Lead (mg/l) & $0.09 \pm 0.02$ & 0.01 & 0.20 & $0.06 \pm 0.08$ & 0.02 & 0.09 & $0.07 \pm 0.01$ & 0.03 & 0.13 & $0.01-1.0$ \\
\hline Zinc $(\mathrm{mg} / \mathrm{l})$ & $0.12 \pm 0.004$ & 0.11 & 0.14 & $0.11 \pm 0.003$ & 0.09 & 0.12 & $0.12 \pm 0.008$ & 0.09 & 0.15 & $5-15$ \\
\hline Copper (mg/l) & $0.41 \pm 0.03$ & 0.27 & 0.50 & $0.39 \pm 0.03$ & 0.26 & 0.50 & $0.40 \pm 0.02$ & 0.26 & 0.49 & $0.05-1.5$ \\
\hline Iron $(\mathrm{mg} / \mathrm{l})$ & $2.09 \pm 0.36$ & 1.00 & 3.95 & $2.61 \pm 0.39$ & 1.23 & 4.23 & $2.00 \pm 0.36$ & 1.03 & 3.82 & 20 \\
\hline
\end{tabular}


Similar superscript across the row shows that there is no significant difference between the mean of the stations

Station 1 recorded the highest depth $(2.7 \mathrm{~m})$ throughout the period of study in August while the least depth, $0.63 \mathrm{~m}$ was also in station 1 April 2012. The variations in depth are usually associated with the rainfall pattern of the drainage basin. This indicates that the river gets deeper in the rainy season than the late dry season. Lower depths recorded during the rainy season especially in stations 2 and 3 could be attributed to heavy siltation associated with increase in rainfall exacerbated by the increased floodwater entering the river. The mean flow velocity ranged between $0.13 \mathrm{~m} / \mathrm{s}$ in station 3 and $0.08 \mathrm{~m} / \mathrm{s}$ in station 2 . The least flow velocity recorded was in station 2 (April) and the highest flow velocity recorded was in Station 3 (May). There is a significant difference among the flow velocity of the three stations sampled, $\mathrm{P}<0.05$, only that station 1 and 2 are not significantly different, but station 3 has significantly faster flow velocity. This probably, is as a result of marginal vegetation encroaching into the river waterways and the presence of a bridge between station 1 and 2 . Furthermore, it may be due to influence of river floor, depth and wind current, because the station 3 is the shallowest among the three stations. Hence, the speed is expected to be faster coupled with other climatic factor like wind, as the river flows downward here. Temporally, there was a distinct seasonal pattern in the variation of flow velocity. Flow velocity has a significant faster water current in the wet season $(0.12 \mathrm{~m} / \mathrm{s})$ than in the dry season $(0.08 \mathrm{~m} / \mathrm{s}), \mathrm{P}<0.05$.

The mean transparency ranged between $1.30 \mathrm{~m}$ and $1.01 \mathrm{~m}$. The least transparency recorded, $0.50 \mathrm{~m}$ was in station 1 (April) and the highest transparency recorded throughout the sampling period, $2.30 \mathrm{~m}$ was also in Station 1 (September).The transparency values recorded indicated that station 2 was a clear zone with high transparency values. This supported the result recorded for turbidity; that stations 1 and 3 are more turbid than station 2, where the sandy floor of the river could be seen clearly from the water surface. A mean value of $1.28 \mathrm{~m}$ in the dry season against $1.14 \mathrm{~m}$ of rainy season indicates that total solids of the water will reduce drastically as rainfall reduces. The $\mathrm{pH}$ values revealed that the water is slightly acidic in nature with a range of 5.76 to 6.01 . The $\mathrm{pH}$ was highest in stations 1 (6.80, November) and the lowest value at station 3 (5.19, April). The mean $\mathrm{pH}$ concentration does not exceed the freshwater local and international standard limits (of $6.5-8.5)$. The $\mathrm{pH}$ range in this study indicates that the water was generally acidic with occasionally slight alkaline condition a characteristic of tropical water; with $\mathrm{pH}$ ranging from 4 to neutrality (Welcomme, 1979). The range recorded in this study is close to 5.54 - 7.31 recorded by Awana (2002) for the same river an indication that the water is becoming more acidic due to increased human activity such as occasional oil spill, dredging, local brewing, and lumbering activities which was prominently observed during the period of study.

Electrical conductivity mean values ranged between $62.03 \mu \mathrm{S} / \mathrm{cm}$ and $70.11 \mu \mathrm{S} / \mathrm{cm}$. A sudden decrease in conductivity was observed in all the stations from the month of August, this was maintained relatively till December. Conductivity is primarily determined in water by the presence and levels of concentration of sodium and magnesium ions and to some extent calcium ions. These ions help buffer the effect of bicarbonate and carbonate ions, thus maintaining the pH (Raymont, 1983). Values of conductivity recorded are an indication of negligible impact of human activities in the area. There is no significant difference $(\mathrm{P}>0.05)$ across the stations and seasonal variation of electrical conductivity. The values are far below WHO maximum limit of $1000 \mu \mathrm{S} / \mathrm{cm}$. The turbidity value was highest in station 1 (5.7 NTU) and the lowest value (3.1 NTU) in station 2. A sudden decrease in turbidity was observed in all the stations from the month of September, this was maintained relatively till December except in Station 3 that has abrupt turbidity increase in October. In this study, turbidity didn't show clear seasonal and spatial patterns. Irregularly higher turbidity values were observed during the rainy season period due to increased suspended solids loads laden run-offs. An occurrence of high turbidity which exceeds the 5.00 NTU Standard limit of FMEnv during peak rainy season (August) was recorded, an indication that the water may not be safe for drinking during rainy season; this might be caused due to runoff from the adjourning environment and the surrounding settlements.

The total solid was highest in station $3(87.3 \mathrm{mg} / \mathrm{l}$, July) and the lowest value (22.7 mg/l, April) was in station 2. Total solid mean values ranged between $38.82 \mathrm{mg} / \mathrm{l}$ and $42.11 \mathrm{mg} / \mathrm{l}$. The trend observed in the stations 2 and 3 are similar with a slight variation in station 1 . There was a clear seasonal variation in total solid; values increased from dry season to rainy season. The mean values of total suspended solid ranged from $5.51 \mathrm{mg} / \mathrm{l}$ to $5.8 \mathrm{mg} / \mathrm{l}$. The Total Suspended Solid was highest in station $1(7.5 \mathrm{mg} / \mathrm{l}$, July) and the lowest value (2.3 mg/l, December) was in station 3 . The trend observed in the stations 1 and 2 are similar with a slight variation in station 3 . The 
mean values of Total dissolve solid ranged from 29.6 $\mathrm{mg} / \mathrm{l}$ to $33.84 \mathrm{mg} / \mathrm{l}$. The total dissolve solid was highest in station 1 (49.1 mg/l, July) and the lowest value (17.6 mg/l, April) was also in station 1 . However, the trend observed in stations 1 and 2 are similar with a slight variation in station 3 . The suspended solids (total) recorded in this study have been recorded elsewhere in Nigeria, (Egborge, 1994). There was no significant marked seasonal difference $(P>0.05)$ in the values observed. Higher values were however recorded in the rainy season than in the dry season- a phenomenon common in most Nigerian inland waters. This could probably be due to the fact that during the rainy season, more run-offs and allochthonous materials are washed into the water bodies. The suspended solids may settle out on the river bed thus impede living organisms' growth and silting up the water body. Though, there was no marked significant difference $(P>0.05)$ across the stations, a significant seasonal difference $(\mathrm{P}<0.05)$ was observed, where higher values were recorded in the rainy season $(44.03 \mathrm{mg} / \mathrm{l})$ than in the dry season $(33.61 \mathrm{mg} / \mathrm{l})$. This supported that turbidity which is more pronounced during the rainy season is a resultant of significant total solid in the water at the same period.

Dissolve oxygen mean values ranges from $7.12 \mathrm{mg} / 1$ to $7.54 \mathrm{mg} / \mathrm{l}$. The dissolve oxygen was highest in station 1 (12.1 mg/l, June) and the lowest in station 3 (5.4 mg/l, September). Low dissolved oxygen was recorded in September at Station 3, could be attributed to the extent of flora composition, organic pollution and population density of fauna. Concentration below $5 \mathrm{mg} / \mathrm{l}$ may adversely affect the functioning and survival of biological communities and below $2 \mathrm{mg} / \mathrm{l}$ may lead to the death of most fishes (Chapman, 1996). There is no significant difference ( $p>0.05)$ in the dissolved oxygen among the stations and no marked difference across the season but the dissolved oxygen was higher in the wet than the dry season. Hence, this accounts for a larger abundance of the zooplankton in the sampled stations during the wet than in the dry months. On a general variation, this reveals that the water was well oxygenated during the period of study. Lower dissolved oxygen values in the same river at Ikpe were recorded ranging from $2.96 \mathrm{mg} / 1$ to $3.80 \mathrm{mg} / \mathrm{l}$ (Edegbe, 2002). During rainy season, as the water level increases, the flow velocity increases and there is bound to be an increase in the dissolved oxygen content. The BOD 5 was highest in station 2 (4.2 mg/l, June) and the lowest value $(0.14 \mathrm{mg} / \mathrm{l}$, September) was in station 1 . The values of $\mathrm{BOD}_{5}$ recorded during the period of study could be attributed to entrance of high organic materials from Ologbo community. In river classification, waters of medium to good quality and unpolluted are those having $\mathrm{BOD}_{5}$ below $6 \mathrm{mg} / \mathrm{l}$. Hence, Ossiomo River could be considered not to be organically polluted.

Alkalinity $\left(\mathrm{HCO}_{3}\right)$ mean value ranges from 48.63 $\mathrm{mg} / \mathrm{l}$ to $53.28 \mathrm{mg} / \mathrm{l}$. The $\mathrm{HCO}_{3}$ was highest in station 2 and 3 concurrently ( $91.5 \mathrm{mg} / \mathrm{l}$, June) and the lowest value $(5.4 \mathrm{mg} / \mathrm{l}$, September). However, the trends observed in all the stations are similar. According to Erondu and Chindah (1991), alkalinity is regarded as a measure of productivity of natural waters. Total alkalinity ranges from $48.63 \mathrm{mg} / \mathrm{l}$ to $53.28 \mathrm{mg} / \mathrm{l}$. Alkalinity was higher during the dry season than in the wet season. Sodium values ranged from $0.32 \mathrm{mg}$ to $5.75 \mathrm{mg} / \mathrm{l}$. These values are moderate. There was no significant marked seasonal pattern $(\mathrm{p}>0.05)$, though lower values were observed during the dry season months than in the rainy season. This seasonality has been observed by Egborge (1978).

The cations namely sodium and potassium mean values ranged from $1.35 \mathrm{mg} / \mathrm{l}$ to $1.43 \mathrm{mg} / \mathrm{l}$ and 0.25 $\mathrm{mg} / \mathrm{l}$ to $0.26 \mathrm{mg} / \mathrm{l}$ respectively. Notably, there was a sudden decrease in the sodium concentration in all the stations, which was sustained till December in the same year. Sodium values were low compared to those of some freshwater bodies in Nigeria (Ogbeibu and Edutie, 2002; Omoigberale and Ogbeibu, 2007 and Ibadin, 2006). Many surface waters, including those receiving waste waters, have concentrations well below 50mg/l. Similar trend was observed in all the stations, however that there was a sudden increase of potassium concentration in October across the three stations. The calcium was highest in station 3 $(1.89 \mathrm{mg} / \mathrm{l}$, May) and the lowest value $(0.01 \mathrm{mg} / \mathrm{l}$, April) was in station1. On the other hand, the concentration of magnesium in all stations was relatively close (between $0.44 \mathrm{mg} / \mathrm{l}$ and $0.52 \mathrm{mg} / \mathrm{l}$ ). In both cases, significant difference was observed in seasonal fluctuations. The values of magnesium are moderately high compared with those of most Nigerian waters bodies; Holden and Green (1960) for River Sokoto; Egborge (1971) for River Oshun; Imevbore, (1975) for Kainji Lake; Okogwu and Ugwumba (2006) for Ologe Lagoon; Omoigberale and Ogbeibu (2007) for River Osse, whose values were below $10 \mathrm{mgl}^{-1}$. The level of magnesium recorded in this study is comparable to some Nigerian water bodies (Omoigberale and Ogbeibu, 2007). Like calcium, seasonality was observed with higher concentrations reported in the wet season and lower values in the dry season months (Odum, 1992). It is clear that the important cations in the Ossiomo River is in the order of, $\mathrm{Na}>\mathrm{Ca}>\mathrm{Mg}>\mathrm{K}$. At the River Niger, the commonest order was $\mathrm{Ca}>\mathrm{Na}>\mathrm{K}>\mathrm{Mg}>$ 
(Imevbore, 1970) while at Oguta Lake it was $\mathrm{Na}>$ Ca> K> Mg (Nwadiaro and Umeham, 1985). The results obtained were similar to the common trend in African water bodies in which sodium is the most important cation (Imevbore, 1970). One major source of calcium in freshwater is the bedrock and weathering of calcium bearing rocks (Waite, 1984). Calcium is often the most common metallic ion in fresh surface water and among the most common in ground water. Calcium values are relatively high compared to $1.11 \mathrm{mgl}-1$ to $9.62 \mathrm{mgl}-1$ for Osse River (Omoigberale and Ogbeibu, 2007) but higher values have also been recorded in some Nigerian waters. Ogbeibu and Edutie (2002) recorded a range of $4.80 \mathrm{mgl}-1$ to $25.0 \mathrm{mgl}-1$ in Ikpoba River and Ibadin (2006) reported values of $0.40 \mathrm{mgl}-1$ to $19.24 \mathrm{mgl}-1$ for Utor River.

Chloride mean values range from $26.44 \mathrm{mg} / \mathrm{l}$ to 36.39 $\mathrm{mg} / \mathrm{l}$. The trend observed in all the stations was similar. Peak values were recorded in the rainy season months and the lower values in the dry season months. Chloride values showed that the river was completely freshwater type in all the study stations. The values were relatively similar to the values of River Osse, Owo River and Ologe lagoon and Ogba River (Omoigberale and Ogbeibu, 2007; Yusuf and Osibanjo, 2007; Anyanwu, 2012). The mean values of phosphorus ranged between $0.25 \mathrm{mg} / \mathrm{l}$ and 0.33 $\mathrm{mg} / \mathrm{l}$. Peak values were recorded in the rainy season months and the lower values in the dry season months. Similar pattern was observed in Phosphate which ranged from $0.07 \mathrm{mg} / 1$ to $0.94 \mathrm{mg} / \mathrm{l}$. These low values were expected, as the water was relatively unpolluted. High phosphate levels have been observed to be associated with organic pollution (Ajayi and Osibanjo, 1981). Similar to what is obtainable in most Nigerian inland waters; peak values were observed in rainy season months when allochthonous phosphorus containing materials are introduced by surface run-off. Different phosphate values in Nigerian rivers had also been reported; $0.17 \mathrm{mg} / \mathrm{l}-0.59 \mathrm{mg} / \mathrm{l}$ in Ossiomo River, (Awana, 2002), $0.26 \mathrm{mg} / \mathrm{l}$ to $1.90 \mathrm{mg} / \mathrm{l}$ in Utor River, Emu, Edo state 2001. Omoigberale and Ogbeibu (2007) reported higher values of $0.28 \mathrm{mg} / 1$ to $3.52 \mathrm{mg} / \mathrm{l}$ for Osse River. An important source of phosphate in Ossiomo River is likely to be from soaps and detergents used in washing of cars and motorcycles, bathing and other laundry activities, which commonly take place in the river. A low level, of phosphate phosphorus is capable of inhibiting the development of plankton.

The Nitrate was highest in station $2(0.71 \mathrm{mg} / \mathrm{l}$, June) and the lowest value $(0.018 \mathrm{mg} / \mathrm{l}$, September) concurrently was in the same station 2 .The mean values of Nitrate $\left(\mathrm{NO}_{3}{ }^{-}\right)$ranges from $0.16 \mathrm{mg} / \mathrm{l}$ to $0.20 \mathrm{mg} / \mathrm{l}$. However, similar trend was observed in all the stations except station 3 which has slightly altered pattern in May. The nitrate-nitrogen concentration obtained in Ossiomo River is relatively low $(0.02-0.69 \mathrm{mg} / \mathrm{l})$ similar to Awana (2002) who recorded as low as $0.06 \mathrm{mg} / \mathrm{l}$ to $0.05 \mathrm{mg} / \mathrm{l}$ in the same river, and it is similar to those reported for other African surface waters. These include $0.11 \mathrm{mg} / 1$ to $0.44 \mathrm{mg} / 1$ for River Sokoto (Holden and Green, 1960$), 0.02 \mathrm{mg} / \mathrm{l}$ to $0.373 \mathrm{mg} / \mathrm{l}$ ) for River Oshun (Egborge, 1971), 0.12mg' to $0.71 \mathrm{mg} / \mathrm{l}$ for some South Eastern Nigerian waters and $0.12 \mathrm{mg} / \mathrm{l}$ to $2.24 \mathrm{mg} / \mathrm{l}$ for Oguta Lake (Nwadiaro and Umeham, 1985$) \quad 0.001 \mathrm{mg} / 1$ to $0.3 \mathrm{mg} / \mathrm{l}$ for River Osse Omoigberale and Ogbeibu (2007). There was an observed seasonal pattern as higher values were recorded for nitrate and sulphate during the rainy season. This pattern was observed by Ogbeibu (1991), where higher values followed periods of rainfall and floods. The low nitrate level in Ossiomo River is an indication of a low level of inorganic pollution in the river. The mean values of sulphate ranged between $0.88 \mathrm{mg} / \mathrm{l}$ and $0.94 \mathrm{mg} / \mathrm{l}$. Sulphate values recorded in this study is lower than $0.8 \mathrm{mg} / \mathrm{l}$ to $4.8 \mathrm{mg} / \mathrm{l}$ for Okhuo River Imoobe (2011) and $0.6 \mathrm{mg} / \mathrm{l}$ to $6,39 \mathrm{mg} / \mathrm{l}$ for Ogba River Anyanwu (2012). High values were recorded in the rainy season months, an indication of marked significant seasonal fluctuations $(\mathrm{P}<0.05)$.

The heavy metals values were generally low. Cadmium values ranged from $0.00 \mathrm{mg} / \mathrm{l}^{-1}$ to $2.01 \mathrm{mg} / \mathrm{l}^{-1}$ with higher value recorded in the rainy season months. Lead ranged from $0.01 \mathrm{mg} / \mathrm{l}^{-1}$ to 0.13 $\mathrm{mg} / \mathrm{l}^{-1}$, most of the high lead values were recorded during the dry season months. The highest zinc value was $0.15 \mathrm{mg} / \mathrm{l}^{-1}$ while the lowest value was $0.09 \mathrm{mg} / \mathrm{l}^{-}$ ${ }^{1}$. The highest copper concentration was $0.26 \mathrm{mg} / \mathrm{l}^{-1}$ while the lowest was $0.50 \mathrm{mg} / \mathrm{l}^{-1}$. The value of iron ranged from $1.00 \mathrm{mg} / \mathrm{l}^{-1}$ to $4.23 \mathrm{mg} / \mathrm{l}^{-1}$. Zinc and copper did not show any clear trend in their temporal variations. There were no significant differences observed among the heavy metals. The results showed that water had low concentrations of heavy metals. The concentrations of heavy metals in Ossiomo River were below the Nigerian standard for drinking water quality.

In conclusion, the physicochemical characteristics and some heavy metal content of Ossiomo River as observed from this study are within the acceptable limits of Federal Ministry of Environment Guideline (FMEnv) and World Health Organisation (2004) standard. The study also showed that there was no evidence of water pollution recorded in any of the 
stations except that its turbidity during peak rainy season indicating that the water may not be safe for drinking except when treated. I recommend that further studies should identify specific sources of pollution, monitor seasonal changes in bacterial incidences and correlate this to outbreaks of waterborne diseases in the community.

\section{REFERENCES}

Adebisi, AA (1981). The Physicochemical hydrology of a Tropical seasonal River Upper Ogun River. Hydrobiologia 79: 157-165.

Ajaiye SO; Adeleye SA (1977). Pollution studies on Nigeria Rivers I: Preliminary report on the pollution level of the River Ona and Ogunpa. Bulletin of Chemical Society of Nigeria 2:7182.

Ajayi, O; Osibanjo, O (1981). Pollution on Nigeria Rivers, II: Water quality of some Nigerian Rivers. Environ Pollution Series, 2: 87-95

American Public Health Association (1998). Standard Methods for the Examination of Water and Wastewater. American Public Health Association. New York, USA. pp1268.

Anyanwu, ED (2012). Physicochemical and some Trace Metal Analysis of Ogba River Benin City, Nigeria. Jordan Journal of Biological Sciences 5: 47-54

Asseez, LO (1967). Review of the Stratigraphy sedimentation and structure of the Niger Delta. In Geology of Nigeria Ed. C.A.Kogbe. pp259272 .

Awachie, JBE (1981). Running Water Ecology in Africa. In Perspectives in Running Water Ecology. (MA Lock ; DD Williams, ed.), New York, Plenum Press. pp339-366.

Awana, BB (2002). The Crustacean zooplankton of Ossiomo River, Ologbo. A B.Sc Thesis, University of Benin, Benin City. pp49.

Battaglia, A; Ghidini, S; Campanini, G; Spaggiari, $\mathrm{R}(2005)$. Heavy metal contamination in little owl (Athene noctua) and common buzzard (Buteo buteo) from Northern Italy. Ecotoxicol. Environ. Saf. 60:61-66.

Caraco, NF; Cole, JJ; Likens, GE; Lovett, G M; Weathers, K C (2003).Variation in nitrate export from flowing waters of vastly different sizes: Does one model fit it? Ecosystems, 6: 344-352.

Chapman, D (1996). Water Quality Assessment: A guide to the use of biota, sediments and water in environmental monitoring. $2^{\text {nd }}$ Edition. Taylor and Francis, London and New York, pp626.

Dike, NI; Ezealor, AU; Oniye, SJ (2004). Concentrations of $\mathrm{Pb}, \mathrm{Cu}, \mathrm{Fe}$ and $\mathrm{Cd}$ during the dry season in River. Jakara, Kano, Nigeria. Chemclass Journal 1:78-81.

Dirisu, AR; Olomukoro JO (2015). Investigation of water quality of two rivers in Agbede Wetland in Southern Nigeria. Global Nest Journal 17(3) 451-562

Donohue, I; McGarrigle, M L; Mills P (2006). Linking catchment characteristics and water chemistry with the ecological status of Irish rivers. Water Research, 40: 91-98.

Edegbe, R (2002). Cladocerans and copepods of Ossiomo River at Ikpe. A B.Sc. Thesis, University of Benin, Benin City. pp 42.

Egborge, ABM (1994). Salinity and the distribution of Rotifers in the Lagos Harbour Badagry Creek system, Nigeria. Hydrobiologia, 272: 95-104.

Egborge, ABM (1971). The chemical hydrology of the River Oshun, Western State, Nigeria. Freshwater Biol., 1: 257 - 271.

Erondu, E S, and Chindah, A C (1991). Physicochemical phytoplankton changes in a tidal freshwater station of the New Calabar River South Eastern Nigeria. Environment and Ecology, 9(3): 561-570.

Fan AM (1996). An introduction to monitoring and environmental and risk assessment of metal. CRC Lewis Publishers, Boca Raton pp5-9.

Gopal, B and Sharma, KP (1990). Ecology of plant population I: Growth. In: Gopal B. (Ed.) Ecology and management of aquatic vegetation in India subcontinent. Kluver Academic Publisher, Netherland. pp79-106.

Holden, MJ; Green, J (1960). Hydrology and plankton of the River Sokoto. .J. Anim. Ecol. 29: 65-84. 
Ibadin, FH (2006). Physicochemical Characteristics and Crustacean Zooplankton of Utor River, Edo State, Southern Nigeria (M.Sc. Thesis). University of Benin, Benin City, Nigeria. pp143.

Igbinosa, EO; Okoh, AI (2009). Impact of discharge wastewater effluents on the physicochemical qualities of a receiving watershed in a typical rural community. International Journal of Environmental Science and Technology. 6:175-182

Ikhuoriah, SO (2014). Physicochemical studies and zooplankton communities of the Ossiomo River, Ologbo, Edo State, Nigeria (M.Sc. Theses) University of Benin, Benin City (Unpublished data)

Ikhuoriah, S O; Oronsaye, C G; Adebanjo, I A (2015). Zooplankton communities of the River Ossiomo, Ologbo, Niger Delta, Nigeria. Animal Research International 12(3): 22492259

Imevbore, AMA (1970). The chemistry of the River Niger in the Kainji reservoir area. Archive Fur Hydrobiologie, 67(3):412 - 431.

Imevbore, AMA (1975). The chemistry of lake Kainji water August 1968- September 1969. In: the ecology of lake Kanji; the transition from river to lakes Ed. A.M.A Imevbore and Adegoke, O.S. University of Press, Ile-Ife. pp 82-102.

Imoobe, TOT (2011) Diversity and Seasonal variation of Zooplankton in Okhuo River, a Tropical Forest River in Edo State, Nigeria. Centrepoint Journal 17: 41-56

Imoobe, TOT; Oboh, IP (2003). Physical and Chemical Hydrology of Jamieson River, Niger Delta, Nigeria. Benin Sci. Dig., 1: 105 - 119.

King, RP (1998). Physicochemical indices of the fisheries potential of a Nigeria rainforest pond. Journal of Aqua. Sc. 13:49-54.

Mandalam P; Upadhyay, R ; Hasan, A (2009). Seasonal and spatial variation of Yamuna River water quality in Delhi, India. Environ Monit Assess, DOI 10.1007/s10661-0091265-2.
Mohiuddin, KM; Zakir, H M; Otomo, K; Sharmin S;Shikazono, N (2010). Geochemical distribution of trace metal pollutants in water and sediments of downstream of an Urban River. Int. J. Environ. Sci. Tech., 7: 17-28.

Nwadiaro, CS; Umeham, SN (1985). The Chemical Hydrology of Oguta lake, Imo State, Southern Nigerian. Arch. Hydrobiol. 105: 241-269

Odum, O (1992). The Ecology and Biology of the fishes of Ethiope River, Nigeria (Ph.D Thesis). University of Benin, Benin City, Nigeria. 222pp.

Ogbeibu, A E (2005). Biostatistics: A Practical Approach to Research and Data Handling. Mindex Publishing Company Limited, Benin City, Nigeria.

Ogbeibu, EA; Edutie, LO (2002). Effects of brewery effluents on water quality and rotifers of the Ikpoba River, Southern Nigeria. African $J$ of Enviro, Pollution and Health, 1(1): 1 - 12.

Ogbeibu, AE (1991). Hydrobiological Characteristics of water bodies in the Okomu Forest Reserve (Sanctuary), Benin City, Nigeria. (Ph.D. Thesis). University of Benin, Benin City, Nigeria. pp257.

Okogwu, OI; Ugwumba, OA (2006). The zooplankton and environmental characteristics of Ologe Lagoon, South West Nigeria. The Zoologist, 1 (4):86 - 92.

Omoigberale, MO; Ogbeibu, AE (2007). Assessing the Environmental Impacts of Oil Exploration and Production on the Water Quality of Osse River, Southern Nigeria. Global J of Environ Sciences, 6(1):1 - 13 .

Orimoogunje OIO; Oyinloye OR; Momodou S (2010). Geospatial Mapping of Wetlands Potential in Ilesa, Southwestern Nigeria FIG Working Week.

Perez-Lopez, M; Cid, F; Oropesa, AL; Hidalgo, LE; Lopez-Beceiro, A; Soler, F. ( 2006). Heavy metal and arsenic content in seabirds affected by Prestige oil spill on the Galician coast (NW Spain). Sci. Total Environ. 359 (13): 209-220. 
Short, K C; Stauble, A J (1967). Outline of the geology of Niger Delta. A. A. P. G, 51:761779

Silambarasan, K; Senthilkumaar V; Velmurugan, K (2012). Studies on the distribution of heavy metal concentrations in river Adyar, Chennai, Tamil Nadu. Eur. J. Exp. Biol. 2: 2192-2198.

Tawari-Fufeyin P; Imoobe, TOT.; Awana, BB (2008). The impact of bridge construction on the crustacean zooplankton of Ossiomo River, Niger Delta Nigeria. African Scientist 9:117-122

Waite, T D (1984). Principles of water quality. Academic Press. San Diego.

Wayland M; Neugebauer E; Bollinger, T (1999). Concentration of lead in liver, kidney, and bone of bald and golden eagle. Arch. Environ. Contam. Toxicol. 37(2):267-272

Welcomme, R C (1979). The inland fisheries of Africa. CIFA Occassional Papers, 7: 77.
Yusuf, KA ; Osibanjo, O (2007). Nutrients in a Freshwater lagoon, Lagos, Nigeria. Pakistan $J$ of Scientific and Industrial Res., 50 (4): 232 -239 .

Zar, J H (1984). Biostatistical Analysis $2^{\text {nd }}$ ed. Prentice Hall Inc. New Jersey, pp71. 